\title{
KNOWLEDGE MANAGEMENT AND PERCEIVED ORGANISATIONAL INNOVATIVENESS IN GLOBAL ORGANISATIONS
}

\section{Škudienè, V., Augutytè-Kvedaravičienè, I., Gabrielaitytè, U.}

Vida Škudienè/ ISM University of Management and Economics, Arkliy str. 18, Vilnius LT-01305, Lithuania.Email: vidsku@ism.It

leva Augutytè-Kvedaravičienè/ ISM University of Management and Economics, Arkliu str. 18, Vilnius LT 01305, Lithuania.Email: ievkve@ism.It

Ugne Gabrielaityte/ ISM University of Management and Economics, Arkliy str. 18, Vilnius LT-01305, Lithuania. Email: ugne.gabrielaityte@gmail.com

\section{Abstract}

This paper aims to examine how knowledge management is associated with perceived organisational innovativeness in global companies operating in Central European country and what role in this relationship is played by organisational environment stimulants organisational trust, leadership support, training and access to resources, and information and communication technology (ICT). This empirical study used a quantitative approach with the data gathered by questionnaire from global companies functioning in IT service (94) and in money transfer service (109). The findings revealed that knowledge management is significantly associated with perceived organisational innovativeness in the global organisations' context. Organisational environment stimulants (organisational trust, leadership support, training and access to resources, ICT) were confirmed to have a moderate positive association with perceived organisational innovativeness and mediated the relationship between knowledge management and perceived organisational innovativeness. The findings provide additional insights into the existing research on global companies' knowledge management and suggest that global organisations aiming to foster their innovativeness through knowledge management should focus on the development of learning capability and orientation at the organisational level, as well as reconsider their level of organisational trust and leadership support perceived by employees. This research contributes to the literature by examining the relationship between knowledge management and perceived organisational innovativeness and looking into organisational environment stimulants' role in this link in a specific global organisations' context.

Implications for Central European audience: when more and more global IT or financial service providers are looking for options to expand their business across the international borders, Central European countries like Lithuania become an attractive destination. The recommendations derived from the results indicate that leadership in global organisations should strive to create a sense of benevolence and aim to maintain integrity between communication and behaviour, particularly focusing on organisational trust development. Global business organisations' managers must be able to communicate values and norms in a clear and transparent manner as well as ensure that organisational policies are governed 
in a coherent way across the offices around the world.

Keywords: knowledge management; perceived organisational innovativeness; Lithuania JEL Classification: M16

\section{Introduction}

In contemporary business, world innovativeness is considered a vital factor of business companies' successful growth. Moreover, the development of perceived organisational innovativeness is acknowledged as an effective way to survive in today's highly competitive economic environment (Lee \& Kelkar, 2013). Research claims that the level of Perceived Organizational Innovativeness by employees can promote certain individual behaviours, such as engagement in innovation and decision-making at the organisational level. Baertsch (1991) suggested that Perceived Organizational Innovativeness can be equalised to actual innovation adoption as it reflects employee problem solving, ability to deal with organisational change and is linked to the diffusion of innovations across the organisation.

The recent discourse among both scholars and practitioners suggests that knowledge management-based issues are tightly knit firm's innovativeness (Inkinen et al., 2015; Quintane et al., 2011; Rasmussen \& Nielsen, 2011). In turn, both innovation and knowledge creation or sharing are dependent on a supportive organisational setting. Gloet and Terziovski (2004) agree that the role of organisational context has an influence on knowledge management processes, and certain elements should be taken into account when developing strategies for knowledge management and innovation. While 'organisations' inability to create social capital represents the largest obstacle to knowledge management implementation' (Mason \& Pauleen, 2003, p. 46), organisations need to focus on organisational dimensions that encourage employee participation in knowledge management behaviours which in turn foster innovation. As knowledge creation and sharing depend on employee willingness to collaborate in pursuit of innovation, healthy social environment, and workplace relationships are even more critical to global organisations due to complexity that arises through the multinational context. Such a complexity manifests as high flows of intake and output information, highly diversified staff, different cultures, which are all embedded into the context that calls for specific knowledge and innovation management architecture. Companies that operate globally possess diverse social capital and face the challenge of systemising the scattered information to facilitate knowledge exchange and enhance their innovation capabilities. Additionally, such companies must be able to manage global control and coordinate knowledge and innovation processes (Oparaocha, 2016). Knowledge management may be problematic in global companies as they face challenges in globalising and re-creating local knowledge into the new context.

These processes with an emphasis on employee knowledge sharing and innovation drive are conditioned by social interactions and relational exchanges between global entities. Hence, the effectiveness of knowledge and innovation processes in a global company depends on its capability to leverage and harmonise its diverse human resources, enabling them to collaborate and be willing to innovate. The organisational environment may nurture the human resource component in knowledge and innovation processes via supportive leadership, ICT, training, and culture, where employees feel safe to share information and 
provide innovative ideas (Ellonen et al., 2008; Lin, 2007). However, global companies are subjected to an additional set of challenges related to cultural barriers and distance. Global companies are embedded in a specific structural context, the specific network of exchanges, and interactions built on the social capital within a company. However, there is a lack of research on the interplay between knowledge management and innovation drive in geographically scattered companies (Björkman \& Lervik, 2007; Brock \& Siscovick, 2007; Espedal et al., 2012; Evans et al., 2010; Oparaocha, 2016).

According to Gloet and Terziovski (2004), the blind side in the extant literature is the analysis of knowledge management process in relation to the innovation process, as a large number of authors focus their research solely on the improvement of innovativeness in organisations. Meanwhile, a deeper investigation of the supportive role that knowledge management plays in the innovation process and its effects remains under-researched (Darroch, 2005; Du Plessis, 2007). Additionally, Quintane et al. (2011) identify that current measurement and interpretations of innovation as an outcome based on knowledge lacks clarity and call for theoretical justification for a knowledge-based approach to innovation that could be operationalised in future empirical studies.

In response to the fragmented understanding of the relationship between knowledge management in the innovation process, this study addresses the question How is knowledge management related to perceived organisational innovativeness and what is the role of certain organisational environment stimulants in this relationship? More specifically, the aim of this study is to examine how knowledge management components, namely knowledge sharing, knowledge creation and knowledge self-efficacy, are associated with perceived organisational innovativeness in global companies.

\section{Theoretical background}

Knowledge is an organisational resource that can be located in individuals, or collectives, embedded in organisational routines, rules, procedures or processes (De Long \& Fahey, 2000; Barley et al., 2018). Knowledge management in an organisation is intended to leverage and integrate knowledge held by individual employees to exploit this resource for the purposes of the organisation and generate value. Therefore, knowledge management has been recognised as both a critical opportunity and a challenge for organisations (Barley et al., 2018). Knowledge management may be considered as composed of knowledge sharing, knowledge creation, and knowledge self-efficacy. Knowledge sharing is defined in terms of the willingness of individuals to interact and consult with co-workers in an active manner in order to learn from them (Van den Hooff \& De Ridder, 2004). Knowledge creation may be described 'as the extent to which employees learn from work and devote considerable efforts to create new knowledge and skills' (Chen et al., 2010, p. 858). Knowledge self-efficacy is defined as 'judgments of individuals of their capability to share the knowledge that is valuable to the organisation' (Lin, 2007, p. 321).

Knowledge management as a tool that integrates diverse knowledge has been seen as a potential resource of innovative outcomes (Barley et al., 2018). A meta-analytical study of determinants of organisational innovation revealed that technical knowledge resources, as well as internal and external communication, are significant predictors of organisational innovation (Damanpour, 1991). Organisational innovativeness has been conceptualised as 'organisation's tendency to master, implement, and develop processes or products new to 
the organisation, although the processes or products may not be new to its local or foreign' (Luk et al., 2008, p. 590). Perceived organisational innovativeness is defined in terms of employee organisational willingness or unwillingness to change (Hurt \& Teigen, 1977). In sum, knowledge management in an organisation, including knowledge creation, knowledge sharing, and knowledge self-efficacy, may strengthen organisational innovativeness perceived by employees in global companies. We raise the following hypothesis:

H1. There is a positive relationship between knowledge management and perceived organisational innovativeness in global companies.

Social exchange theorists argue that a reciprocal arrangement develops just when employees develop good workplace relationships in an organisation (Cropanzano \& Mitchell, 2005). Thus, based on Social Exchange Theory, it is expected that appropriate organisational environment is imperative for employees to engage in knowledge creation and sharing. It has been established that multiple elements of the organisational environment are related to organisational innovativeness, namely, organisational trust (Ellonen et al., 2008), leadership support (Lin, 2007), information and communication technology, and training and access to resources (Antonio \& Lemos, 2010). Organisational trust is defined as 'positive expectations individuals have about the competence, reliability and benevolence of organisational members, as well as the institutional trust within the organisation' (Ellonen et al., 2008, p. 162). Leadership support is conceptualised in terms of perceived top management encouragement of knowledge sharing and creation (Lin, 2007). Information and Communication Technology (ICT) is understood as mechanisms and applications that allow sharing and creation of knowledge (such as online databases, virtual communities, groupware or intranet) (Lin, 2007). Information and Communication technology may serve as an important resource in knowledge sharing and creation. Jimenez-Jimenez et al. (2014) stress the importance of communication and suggest focusing on the effect of different communication mechanisms between subsidiaries and parent companies in the knowledge transfer process. Chen et al. (2010) suggest continuing research on variables from the organisational environment that could have a moderating impact on the relationship between knowledge management and innovativeness, such as social interaction and knowledge attribute. Training and access to resources here refer to 'coaching; mentoring and accessibility of people who possess tacit knowledge notwithstanding their hierarchical position' (Antonio \& Lemos, 2010, p. 414).

In line with Social Exchange theory, we hypothesise that such organisational environment stimulants as organisational trust, leadership support, ICT, training and access to resources may facilitate knowledge management in global companies (see Figure 1):

H2. There is a positive relationship between organisational environment stimulants and perceived organisational innovativeness in global companies.

H3. The organisational environment has a moderating influence on the relationship between knowledge management and perceived organisational innovativeness. 


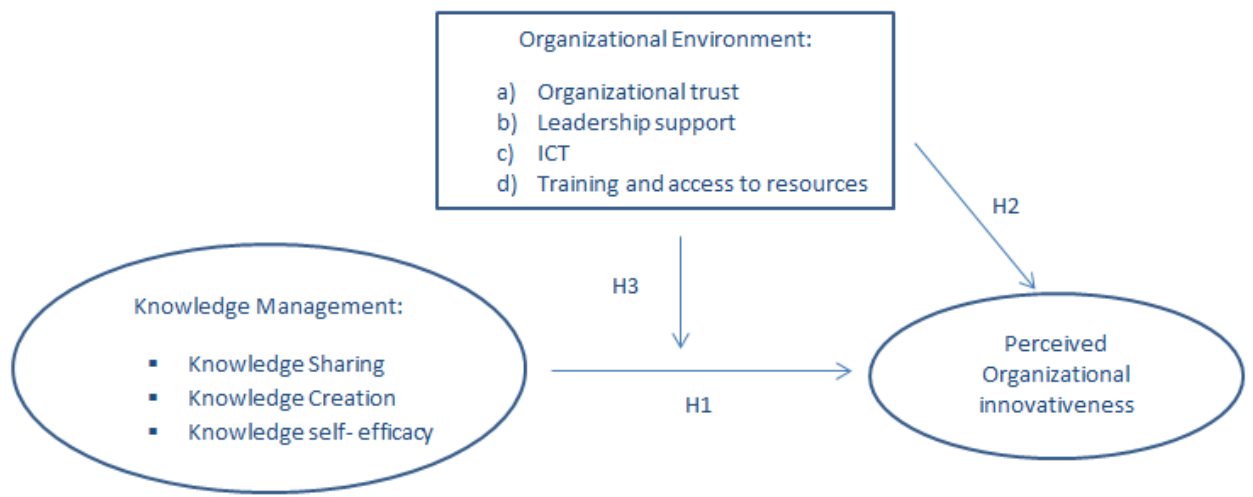

Source: authors' own elaboration

\section{Research methodology}

\subsection{Sample}

Multistage cluster sampling technique was used for this study while the primary sampling unit has been narrowed down to employees in two global corporations. The global large information technology (IT) service and money transfer service corporations have been selected for the study. IT service company's global presence is in 70 countries with headquarters across all continents and 74,000 employees. Money transfer service company global presence is in 200 countries with offices in the three major regions: Asia Pacific, North America, and Europe, employing 12,000 individuals globally. Due to accessibility and internal organisational constraints, the secondary sampling unit will be narrowed down to employees working in subsidiaries of identified organisations that are established in Lithuania. Since both organisations strictly protect their confidentiality and security, the research instrument was distributed through internal online networks to prevent any access issues and ensure a higher participation rate. Out of the 1000 distributed questionnaires, 233 were received, and 203 responses in total were used for data analysis: 94 from IT service company, and 109 from money transfer service company.

\subsection{Measures}

Perceived organisational innovativeness. As discussed above, the innovation construct in this research will be operationalised and measured through a dependent variable perceived organisational innovativeness that was defined in terms of perceived organisational willingness or unwillingness to change (Hurt \& Teigen, 1977). PORGI scale, originally developed and used in research by Hurt and Teigen (1977), was selected for the measurement of this variable. The construct of Perceived Organizational Innovativeness (PORGI) has been introduced by Hurt and Teigen (1977) and defined in terms of employees' perceptions of organisational willingness to change. Authors claim that level of PORGI can help to determine certain individual behaviours, such as engagement in innovation and 
decision-making at the organisational level. Also PORGI can help to identify employees' satisfaction with employment and communication. Baertsch (1991) is one of the few researchers who have studied employee-organisation relationships in the context of PORGI and suggested that this construct can be equalised to actual innovation adoption as it reflects employee problem solving and ability to deal with organisational change and is linked to the diffusion of innovations across organisation. As there's a lack of studies that would measure innovation through this construct, there is a clear need for further investigation of what factors may have an influence on PORGI and determine how organisations would be able to foster it.

The research instrument was designed from a number of different studies. Internal consistency and reliability of scales will have to be tested to ensure homogeneity of items for each construct (Gaur \& Gaur, 2007). Internal consistency and reliability will be evaluated using Cronbach's Alpha $(\alpha)$ test in SPSS that measures inter-correlations between individual items. The higher coefficient of Cronbach's Alpha $(\alpha)$ indicates that all items measure the same phenomenon and that similar results could be expected if this instrument would be used in a different study. It is also important to test the validity of the research instrument in order to determine if it actually measures the relationship between constructs it was designed to measure. Gaur \& Gaur (2007) indicates three other types of validity - predictive, content and construct. Since it is impossible to define the total domain of items, the predictive and content validity of this instrument was not tested. Two negatively worded items were included in the study, as according to DeVellis (2003), reverse questions prevent several types of individual bias (an agreement, affirmation, acquiescence) when respondents tend to accept and confirm all statements irrespective of their content. The construct was measured through five items in the questionnaire, two of which were worded negatively (Q3 and Q5). Even though reverse questions have been recoded into new variables, initial Cronbach's $\propto(0.757$ and 0.530 for Organization A and B, respectively) revealed that removing Q3 would improve internal consistency and reliability of this scale for both samples. Therefore, Q3 was removed from further analysis, resulting in higher Cronbach's $\propto$ for both organisations $(0.767$ and 0.663 for Organization $A$ and $B$, respectively) fulfilling minimum required satisfactory value of 0.6 .

Knowledge management construct was assessed using three indicators: knowledge sharing (Van den Hooff \& De Ridder, 2004), knowledge creation (Griese et al., 2012), and knowledge self-efficacy (Lin, 2007) (Cronbach's $\propto$ was 0.834 for Organization A, and 0.891 for Organization B). Organisational environment construct was measured through four indicators: organisational trust (Ellonen et al., 2008), leadership support (Lin, 2007), information and communication technology (Lin, 2007), and training \& access to resources (Antonio \& Lemos, 2010) (Cronbach's $\propto$ was 0.907 and 0.919 for Organization A and B, respectively). Demographic and organisational characteristics such as type of organisation, working experience, position, gender, age, and education level were assessed through dichotomous and multinomial items.

\subsection{Data analysis methods}

Pearson or Spearman correlation tests were applied to investigate the relationship between two variables, while the partial correlation was applied to examine the relationship between two specific variables. Comparison of means for two samples was performed through independent samples t-test or Mann-Whitney $U$ test depending on the normality of distribution 
of the results in both samples. One-tailed Spearman correlation test has been selected to measure the strength and direction of relationship among both, dependent and independent variables, as all were measured on an ordinal scale and raised hypotheses assumed positive monotonic relationship between constructs. Guildford's categorisation (1956) was used to interpret and evaluate the strength of the relationship based on correlation coefficient results.

\section{Results}

\subsection{Descriptive analysis}

The sample size was $\mathrm{N}=203$, with 94 respondents from organisation A (IT services) and 109 respondents from organisation $B$. The respondents were represented by a similar number of male and female respondents - 57\% males and 43\% females in Organization A, and $47 \%$ males and $53 \%$ females in organisation $B$. In terms of age, the majority of respondents in both organisations fell into 25 - 40-year interval $76 \%$ and $52 \%$ in Organizations $A$ and $B$, respectively). In terms of educational level, the majority of respondents hold a post-graduate degree (53\% and $61 \%$ in Organization A and B, respectively). In terms of working experience, respondents in both organisations were relatively recently employed as the majority had been working up to 3 years (52\% and $67 \%$ in Organization A and B, respectively). The majority of respondents held employee rather than managerial position within a company $(79 \%$ and $90 \%$ in Organization A and B, respectively). The means and standard deviations for variables examined in the study are presented in Table 1. Correlations of variables examined in the study are presented in Table 2.

Table 1 | Means and standard deviations of study variables

\begin{tabular}{lllllllllll}
\hline Factor & PORGI & KM & KS & KC & KSE & OE & OT & LS & ICT & T \\
\hline Organization & & & & & & & & & & \\
A & & & & & & & & & \\
\hline Mean & 5.16 & 5.87 & 6.10 & 5.52 & 5.87 & 5.25 & 5.61 & 5.26 & 5.50 & 4.64 \\
SD & 1.12 & 0.97 & 0.98 & 1.41 & 1.09 & 1.20 & 1.16 & 1.45 & 1.43 & 1.40 \\
\hline Organisation & & & & & & & & & & \\
B & & & & & & & & & & \\
\hline Mean & 4.91 & 5.63 & 5.80 & 5.49 & 5.43 & 5.20 & 5.56 & 5.27 & 5.29 & 4.69 \\
SD & 0.94 & 0.99 & 1.03 & 1.19 & 1.25 & 1.08 & 1.10 & 1.17 & 1.31 & 1.28 \\
\hline
\end{tabular}

Note: PORGI $=$ Perceived organizational innovativeness, $\mathrm{KM}=$ knowledge management, $\mathrm{KS}=$ knowledge sharing, $\mathrm{KC}=$ knowledge creation, $\mathrm{KSE}=$ knowledge self-efficacy, $\mathrm{OE}=$ organizational environment, OT = organizational trust, LS = leadership support, ICT = information and communication technology, $\mathrm{T}=$ training; ${ }^{*} p<0.05 ;{ }^{* *} p<0.01$

Source: authors' own calculation 
Table 2 | Correlations of study variables

\begin{tabular}{|c|c|c|c|c|c|c|c|c|c|}
\hline Factor & KM & KS & KC & KSE & OE & OT & LS & ICT & $T$ \\
\hline $\begin{array}{l}\text { PORGI (Org. } \\
\text { A) }\end{array}$ & 0.366 & 0.282 & 0.378 & 0.230 & $0.620^{* *}$ & $0.524^{\star *}$ & $0.573^{\star \star}$ & $0.490^{* *}$ & $0.550^{* *}$ \\
\hline $\begin{array}{l}\text { PORGI (Org. } \\
\text { B) }\end{array}$ & $\underbrace{0.546}_{* *}$ & $\underset{* *}{0.375}$ & $\underset{* *}{0.662}$ & $\underset{* *}{0.445}$ & $0.643^{* *}$ & $0.653^{\star *}$ & $0.528^{* *}$ & $0.481^{* *}$ & $0.616^{\text {** }}$ \\
\hline
\end{tabular}

Note: PORGI $=$ Perceived organizational innovativeness, $\mathrm{KM}=$ knowledge management, $\mathrm{KS}=$ knowledge sharing, $\mathrm{KC}=$ knowledge creation, $\mathrm{KSE}=$ knowledge self-efficacy, $\mathrm{OE}=$ organizational environment, OT = organizational trust, LS = leadership support, ICT = information and communication technology, $T=$ training; * $p<0.05 ;{ }^{* *} p<0.01$

Source: authors' own calculation

$\mathrm{H} 1$ that assumed a positive relationship between knowledge management and perceived organisational innovativeness constructs was confirmed with the Spearman correlation test. The sample from Organization A showed a low positive correlation $(\rho A=0.366)$, while results for sample from Organization $B$ revealed correlation at a moderate level $(\rho B=0.546, p<$ 0.01). A tendency for PORGI values to increase is observed as knowledge increases.

When analyzing individual correlations between components of knowledge management construct, results from both organizations revealed that knowledge creation has the strongest relationship with perceived organizational innovativeness $(\rho A=0.378 ; \rho B=0.662, p<0.01)$. For Organization $A$, the next strongest correlation was between knowledge sharing $(\rho \mathrm{A}=$ $0.282, p<0.01)$ followed by knowledge self-efficacy $(\rho A=0.230, p<0.05)$, while for Organization $B$ knowledge self-efficacy had stronger relationship $(\rho B=0.445, p<0.01)$, followed by knowledge sharing $(\rho \mathrm{B}=0.375, \mathrm{p}<0.01)$.

The Spearman correlation test for $\mathrm{H} 2$ confirmed the positive relationship between organisational environment stimulants and Perceived Organisational Innovativeness indicators. Correlation coefficients for both organizations showed moderate positive correlation $(\rho \mathrm{A}=0.620, \rho \mathrm{B}=0.643, \mathrm{p}<0.01)$.

Results confirmed substantial statistically significant positive relationship between organizational environment stimulants and Perceived Organizational Innovativeness indicators $(\mathrm{R} 2=0.413, \mathrm{p}<0.01)$. Analysis of correlations between individual components of organizational environment stimulants and Perceived Organizational Innovativeness indicators revealed different results for each organization. For Organization $A$ the strongest correlating variable was leadership support $(\rho A=.573, p<0.01)$ followed by training and access to resources $(\rho A=0.550, p<0.01)$, organizational trust $(\rho A=0.524, p<.01)$ and $I C T$ $(\rho A=0.490, p<0.01)$. Results from Organization $B$ indicated the strongest correlation between organizational trust $(\rho \mathrm{B}=.653, \mathrm{p}<0.01)$ followed by training/access to resources $(\rho \mathrm{B}=0.616, \mathrm{p}<0.01)$, leadership support $(\mathrm{pB}=0.528, \mathrm{p}<0.01)$ and ICT $(\mathrm{pB}=0.481, \mathrm{p}<$ $0.01)$.

To test $\mathrm{H} 3$ (which assumed that the organisational environment stimulants moderate the relationship between knowledge management and perceived organisational innovativeness in global companies), partial correlation test was applied (Gaur \& Gaur, 2007). As following the relationship between organisational environment stimulants and perceived organisational innovativeness, a statistically significant strong correlation $(\rho A=0.731 ; \rho B=0.734, p<0.01)$ 
between organisational environment stimulants and knowledge management was confirmed (see Table 3). A partial correlation test was confirmed as an appropriate method for testing $\mathrm{H} 3$, as organisational environment stimulants construct is correlated with both - knowledge management and perceived organisational innovativeness. Results of the partial correlation test showed that correlation coefficients when controlling for organisational environment stimulants in both samples dropped and $p$ values increased above 0.01 alpha level, thus confirming that organisational environment stimulants mediate the relationship between knowledge management and perceived organisational innovativeness $(\mathrm{H} 3)$, as showed in Table 4.

Table 3 | Correlation between organisational environment and knowledge management

\begin{tabular}{llll|r|r}
\hline & & & OE_average & KM_average \\
\hline $\begin{array}{l}\text { Spearman's } \\
\text { rho }\end{array}$ & Org A & OE_average & $\begin{array}{l}\text { Correlation } \\
\text { Coefficient } \\
\text { Sig (1-tailed) }\end{array}$ & 1.000 & $0.731^{* *}$ \\
& & & $\cdot$ & 0.000 \\
\cline { 2 - 6 } & Org B & OE_average & $\begin{array}{l}\text { Correlation } \\
\text { Coefficient } \\
\text { Sig (1-tailed) }\end{array}$ & 1.000 & $0.734^{* *}$ \\
& & & \\
\end{tabular}

Note: ${ }^{* *}$. Correlation is significant at the 0.01 level (1-tailed).

Source: authors' own calculation

Table 4 | Partial correlations

\begin{tabular}{|c|c|c|c|c|c|}
\hline $\begin{array}{l}\text { Type of } \\
\text { Organization }\end{array}$ & $\begin{array}{l}\text { Control } \\
\text { Variables }\end{array}$ & & & KM_average & $\begin{array}{l}\text { PORGI_ } \\
\text { average }\end{array}$ \\
\hline \multirow[t]{2}{*}{$\begin{array}{l}\text { Organization } \\
\text { A }\end{array}$} & OE_average & KM_average & $\begin{array}{l}\text { Correlation } \\
\text { Significance } \\
\text { (1-tailed) } \\
\text { Df }\end{array}$ & $\begin{array}{r}1.000 \\
0\end{array}$ & $\begin{array}{r}-0.241 \\
0.010 \\
91\end{array}$ \\
\hline & & PORGI_average & $\begin{array}{l}\text { Correlation } \\
\text { Significance } \\
\text { (1-tailed) } \\
\text { Df }\end{array}$ & $\begin{array}{r}-0.241 \\
0.010 \\
91\end{array}$ & $\begin{array}{r}1.000 \\
0\end{array}$ \\
\hline \multirow[t]{2}{*}{$\begin{array}{l}\text { Organisation } \\
\text { B }\end{array}$} & & & $\begin{array}{l}\text { Correlation } \\
\text { Significance } \\
\text { (1-tailed) } \\
\text { Df }\end{array}$ & $\begin{array}{r}1.000 \\
0\end{array}$ & $\begin{array}{r}0.199 \\
0.019 \\
106\end{array}$ \\
\hline & & & $\begin{array}{l}\text { Correlation } \\
\text { Significance } \\
\text { (1-tailed) } \\
\text { Df }\end{array}$ & $\begin{array}{r}0.199 \\
0.019 \\
106\end{array}$ & $\begin{array}{r}1.000 \\
0\end{array}$ \\
\hline
\end{tabular}

Source: authors' own calculation

As some differences between results from two organisations have been observed when testing hypotheses on the relationships, a detailed comparison of mean values for all constructs and variables was conducted. The mean value for perceived organisational innovativeness in the sample from Organization $A(5.16)$ is slightly higher than for Organization B (4.91). As correlation coefficients in a sample from Organization B were 
higher, a detailed analysis was also conducted for means of knowledge management construct. The mean values in sample from Organization A were higher for knowledge management construct $(\mu \mathrm{A}=5.87, \mu \mathrm{B}=5.63)$ and all individual variables - knowledge sharing $(\mu \mathrm{A}=6.1, \mu \mathrm{B}=5.8)$, knowledge creation $(\mu \mathrm{A}=5.52, \mu \mathrm{B}=5.49)$, knowledge selfefficacy $(\mu A=5.87, \mu B=5.43)$ compared to sample from Organization $B$. Mean values in sample from Organization A were slightly higher for overall organizational environment construct $(\mu \mathrm{A}=5.25, \mu \mathrm{B}=5.20)$ and also following individual variables - organizational trust $(\mu \mathrm{A}=5.61, \mu \mathrm{B}=5.56)$ and $I C T(\mu \mathrm{A}=5.5, \mu \mathrm{B}=5.29)$ and nearly equal/slightly lower for leadership support $(\mu \mathrm{A}=5.26, \mu \mathrm{B}=5.27)$ and training $(\mu \mathrm{A}=4.64, \mu \mathrm{B}=4.69)$ compared to sample from Organization $B$.

Since the observed distribution in collected data is non-normal, the Mann-Whitney $U$ test has been chosen to see if observed differences between two samples are statistically significant (results are presented in Table 5). Firstly, samples were compared on the dependent variable - PORGI perceived organisational innovativeness. Results showed that observed differences between the two samples are statistically insignificant as $p$-value exceeded 0.05 alpha level. When comparing samples on the KM knowledge management construct, results appeared to be significantly different for the overall construct as well as knowledge sharing and knowledge self-efficacy as $p$ values for these variables fell behind 0.05 alpha level. For organisational environment construct, again observed differences between the two samples appeared to be statistically insignificant as $p$ values were higher than 0.05 .

Table 5 | Comparison of statistical significance in differences between two samples

\begin{tabular}{lllll}
\hline Factor & $\begin{array}{l}\text { Mann- } \\
\text { Whitney U }\end{array}$ & Wilcoxon W & $\mathbf{Z}$ & $\begin{array}{l}\text { Asymp. Sig. } \\
\text { (2-tailed) }\end{array}$ \\
\hline PORGI & 4327.500 & 10322.500 & -1.912 & 0.056 \\
OE & 4888.500 & 10883.500 & -0.562 & 0.574 \\
KM & 4223.000 & 10218.000 & -2.165 & 0.030 \\
KS & 4143.500 & 10138.500 & -2.374 & 0.018 \\
KC & 4725.000 & 10720.000 & -0.968 & 0.333 \\
KSE & 4058.000 & 10053.000 & -0.550 & 0.006 \\
OT & 4897.500 & 10892.500 & -0.653 & 0.582 \\
LS & 4853.500 & 10848.500 & -1.485 & 0.514 \\
ICT & 4510.500 & 10505.500 & -0.373 & 0.138 \\
T & 4968.500 & 9433.500 & -2.734 & 0.709 \\
\hline
\end{tabular}

Note: PORGI = Perceived organizational innovativeness, $K M=$ knowledge management, $K S=$ knowledge sharing, $K C=$ knowledge creation, $K S E=$ knowledge self-efficacy, $O E$ = organizational environment, $O T=$ organizational trust, $L S=$ leadership support, ICT = information and communication technology, $T$ = training.

Source: authors' own calculation

We further controlled for demographic variables, such as respondent's age, educational background, professional experience and position. When looking at the relationship with perceived organisational innovativeness, results revealed only one statistically significant negative relationship with respondent's age $(\rho=-0.236, p<0.01)$. A negative correlation with age has also been observed in the analysis of the relationship between demographic 
variables and knowledge management construct $(\rho=-0.175, p<0.01)$, please, see Tables 6 and 7 below.

Table 6 | Correlation results between demographic variables and PORGI

\begin{tabular}{|c|c|c|c|c|c|c|c|c|}
\hline & & & $\begin{array}{l}\text { PORGI } \\
\text { average }\end{array}$ & $\begin{array}{l}\text { Working } \\
\text { experience }\end{array}$ & Position & Gender & Age & $\begin{array}{l}\text { Educati } \\
\text { on level }\end{array}$ \\
\hline \multirow[t]{3}{*}{$\begin{array}{l}\text { Spearm } \\
\text { an's rho }\end{array}$} & $\begin{array}{l}\text { PORGI } \\
\text { average }\end{array}$ & $\begin{array}{l}\text { Correlation } \\
\text { Coefficient }\end{array}$ & 1.000 & -0.084 & 0.049 & 0.120 & $-0.236^{\star \star}$ & 0.000 \\
\hline & & $\begin{array}{l}\text { Sig. } \\
\text { tailed) }\end{array}$ & . & 0.234 & 0.488 & 0.089 & 0.001 & 0.996 \\
\hline & & $\mathrm{N}$ & 203 & 203 & 203 & 203 & 203 & 203 \\
\hline
\end{tabular}

Note: ${ }^{* *}$. Correlation is significant at the 0.01 level (2-tailed).

Source: authors' own calculation

Table 7 | Correlation results between demographic variables and knowledge management

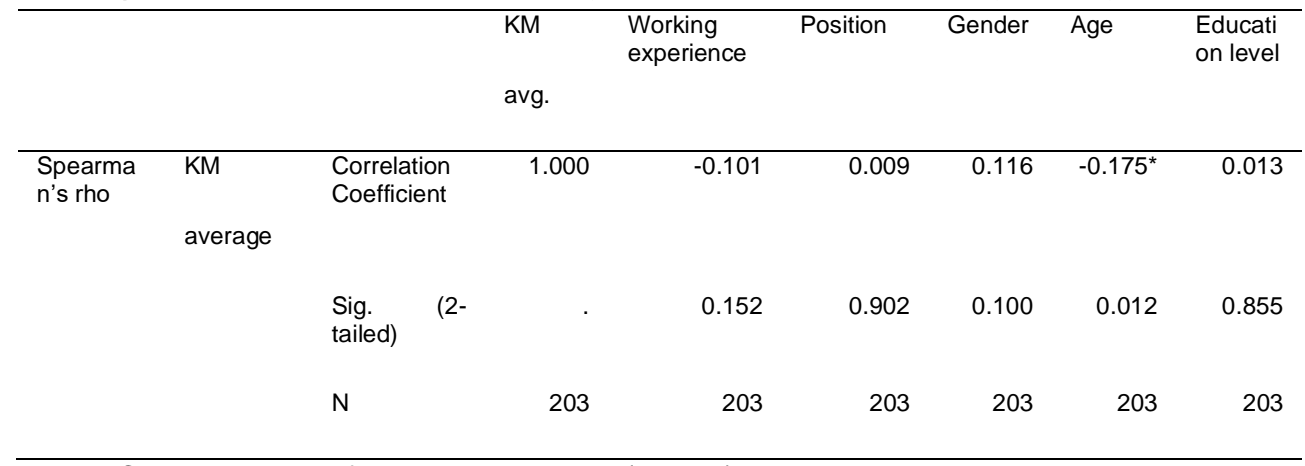

Note: ${ }^{*}$. Correlation is significant at the 0.05 level (2-tailed).

Source: authors' own calculation

\section{Discussion and conclusions}

Firstly, the conceptualised relationship between knowledge management and perceived organisational innovativeness was confirmed in this study. In the absence of the studies that had investigated associations between these two constructs in global companies, this finding could be aligned with the research results by Chen et al. (2010), who approached innovation phenomena from an organisational innovativeness perspective in Taiwanese firms and concluded that capabilities of knowledge creation and sharing were driving this construct. Furthermore, results show that knowledge creation has the strongest association with perceived organisational innovativeness in global organisations. This finding supports results from the study conducted by Griese et al. (2012), who approached this variable from a knowledge generation perspective and concluded that it has a strong influence on the innovativeness of a firm through fostering individual learning, as well as generation and execution of new ideas, products and processes at an organisational level.

Secondly, organisational environment stimulants, defined in terms of organisational trust, leadership support, ICT, training and access to resources, were confirmed to have a 
moderate positive association with perceived organisational innovativeness. When looking at individual components of the organisational environment, organisational trust was confirmed to have the strongest influence on PORGI. This finding supports implications of organisational trust by Sankowska (2013), who suggested that organisational trust is an absolute requisite for knowledge transfer and creation to take place and therefore can also be considered as a cornerstone to organisation's innovativeness, supported by empirical evidence that documented strong associations between mentioned variables in companies listed on the Warsaw Stock Exchange. Ellonen et al. (2008) had indicated that organisational trust is closely related to another element of the organisational environment - leadership support. As management plays a pivotal role in global organisations, their direct actions on transparency and clear communication on organisation's norms and policies across the departments, their individual integrity of actions and words can enhance organisational trust and, consequently - global companies' innovativeness. In terms of other variables, the largest difference was observed in ICT evaluation that clearly indicates technological orientation. ICT variable also had the second-strongest correlation with PORGI in global companies' case. Thus we could claim that it aligns with the research results of the study by Lee and Kelkar (2013) who found that ICT is an important facilitator in the knowledge creation process based on the SECI model. Results of this research show that ICT is related to innovation not only through knowledge management but also has a direct effect on perceived organisational innovativeness in global companies. It thus confirms the proposition by Lee and Kelkar (2013) that knowledge management should be approached by organisations as one of the key areas for encouraging collaboration and continuous learning.

Third, it was determined that the organisational environment stimulants mediate the relationship between knowledge management and perceived organisational innovativeness. This observation confirms the significance of global organisations' environmental settings and provides a significant contribution to the existing theoretical background by adding new organisational variables that play mediating role in this relationship. Organisational learning and dynamic organisational capabilities mediate the relationship between knowledge processes and an organisation's innovativeness.

Finally, out of all demographic variables, employee age in global companies was found to have a weak negative association with perceived organisational innovativeness as well as their attitude to knowledge management activities. Results of this study contradict existing findings from research conducted by Baertsch (1991), who observed that perceived organisational innovativeness was highest among the oldest groups of respondents (aged 40-49 and 50-59). Results from the research in the global company context contradict this insight and suggest that there is a tendency for perceived organisational innovativeness to decrease as the respondent's age increases. However, admittedly, differences in findings could result from different age categorisation or from the specific global companies' structural context.

\section{Implications}

The relationship between knowledge management and the firm's innovativeness surges the continuous improvement of knowledge management processes. The findings of the study reinforce the suggestions by Du Plessis (2007) that one of the most important roles that knowledge management plays in innovation is the creation of tools, processes, and platforms for knowledge creation and sharing, and extend them to a global company context. In this 
vein, further studies embracing these aspects in a global organisational context would contribute to the architecture and management of innovation processes.

Few possible managerial techniques for overcoming barriers are suggested by Bhatt (2000) and Nonaka and Takeuchi (1995). Firstly, to encourage the dynamic process of knowledge generation, managers should be supportive of self-managed teams as self-sufficiency and relative authority leads to more debates, encourages constructive feedback and criticism as well as dialectical thinking in individuals. Furthermore, it is recommended to reconsider how managers understand organisations and challenge the traditional view by interpreting it as a set of individual experiences and social relations rather than codified technological systems and structures. Finally, it is recommended to stay open-minded and analyse organisational knowledgebase from various perspectives, as comparison of different individual interpretations allows to evaluate the usefulness and possible limitations of existing knowledgebase, reconsider what are organisational priorities of global companies and generate ideas for possible improvements of interactions and exchanges among companies' entities in different countries as the quality of these social interactions would have significant implications for employees' engagement into knowledge management practices.

To conclude, the recommendations derived from the results indicate that leadership in global organisations should strive to create a sense of benevolence and aim to maintain integrity between communication and behaviour, particularly focusing on organisational trust development. Global business organisations' managers must be able to communicate values and norms in a clear and transparent manner as well as ensure that organisational policies are governed in a coherent way across the offices around the world.

\section{References}

Antonio, L., \& Lemos, J. (2010). Relevant factors for tacit knowledge transfer within organisations. Journal of Knowledge Management, 14(3), 410-427. https://doi.org/10.1108/13673271011050139.

Baertsch, G. (1991). Effects of organisational identification and perceived organisational innovativeness on the adaptive and innovative behaviors of employees [Dissertation thesis]. University of Montana. Retrieved from https://scholarworks.umt.edu/cgi/viewcontent.cgi?article=3203\&cont ext=etd.

Barley, W. C., Treem, J. W., \& Kuhn, T. (2018). Valuing multiple trajectories of knowledge: A critical review and agenda for knowledge management research. Academy of Management Annals, 12(1), 278-317. https://doi.org/10.5465/ANNALS.2016.0041.

Bhatt, G. (2000). Information dynamics, learning and knowledge creation in organisations. The Learning Organization, 7(2), 89-99. https://doi.org/10.1108/09696470010316288.

Björkman, I., \& Lervik, J. E. (2007). Transferring HR practices within multinational corporations. Human Resource Management Journal, 17(4), 320-335. https://doi.org/10.1111/j.17488583.2007.00048.x.

Brock, D. M., \& Siscovick, I. C. (2007). Global integration and local responsiveness in multinational subsidiaries: some strategy, structure, and human resource contingencies. Asia Pacific Journal of Human Resources, 45(3), 353-373. https://doi.org/10.1177/1038411107082278.

Chen, C., Huang, J., \& Hsiao, Y. (2010). Knowledge management and innovativeness. International Journal of Manpower, 31(8), 848-870. https://doi.org/10.1108/01437721011088548. 
Cropanzano, R., \& Mitchell, M. (2005). Social exchange theory: An interdisciplinary review. Journal of Management, 31(6), 874-900. https://doi.org/10.1177/0149206305279602.

Damanpour, F. (1991). Organisational innovation: A meta-analysis of effects of determinants and moderators. Academy of Management Journal, 34(3), 555-590. https://doi.org/10.2307/256406.

Darroch, J. (2005). Knowledge management, innovation and firm performance. Journal of Knowledge Management, 9(3), 101-115. https://doi.org/10.1108/13673270510602809.

De Long, D. W., \& Fahey, L. (2000). Diagnosing cultural barriers to knowledge management. Academy of Management Perspectives, 14(4), 113-127. https://doi.org/10.5465/AME.2000.3979820.

DeVellis, R. F. (2003). Scale Development: Theory and Applications (2nd ed.). London, UK: Sage Publications.

Du Plessis, M. (2007). The role of knowledge management in innovation. Journal of Knowledge Management, 11(4), 20-29. https://doi.org/10.1108/13673270710762684.

Ellonen, R., Blomqvist, K., \& Puumalainen, K. (2008). The role of trust in organisational innovativeness. European Journal of Innovation Management, 11(2), 160-181. https://doi.org/10.1108/14601060810869848.

Espedal, B., Gooderham, P., \& Evensen, H. (2012). The impact of global leadership development programs on social networks and knowledge sharing in multinational enterprises. Human Resources Management \& Ergonomics, 6(2), 235-244.

Evans, P., Pucik, V., \& Björkman, I. (2010). The global challenge: International human resource management (2nd ed.). New York, NY: McGraw-Hill Higher Education.

Gaur, A. S., \& Gaur, S. S. (2007). Statistical methods for practice and research: A guide to data analysis using SPSS. Thousand Oaks, CA: Sage.

Griese, I., Pick, D., \& Kleinaltenkamp, M. (2012). Antecedent of knowledge generation competence and its impact on innovativeness. Journal of Business and Industrial Marketing, 27(6), 468-485. https://doi.org/10.1108/08858621211251479.

Hurt, H., \& Teigen, C. (1977). The development of a measure of perceived organisational innovativeness. Annals of the International Communication Association, 1(1), 377-385, https://doi.org/10.1080/23808985.1977.11923693.

Inkinen, H. T., Kianto, A., \& Vanhala, M. (2015). Knowledge management practices and innovation performance in Finland. Baltic Journal of Management, 10(4), 432-455. https://doi.org/10.1108/BJM-10-2014-0178.

Jimenez-Jimenez, D., Martínez-Costa, M., \& Sanz-Valle, R. (2014). Knowledge management practices for innovation: A multinational corporation's perspective. Journal of Knowledge Management,

Lee, C., \& Kelkar, R. (2013). ICT and knowledge management: Perspectives from the SECI model. The Electronic Library, 31(2), 226-243. https://doi.org/10.1108/02640471311312401.

Lin, H. (2007). Knowledge sharing and firm innovation capability: An empirical study. International Journal of Manpower, 28(3/4), 315-332. https://doi.org/10.1108/01437720710755272.

Luk, C. L., Yau, O. H. M., Sin, L. Y. M., Tse, A. C. B., Chow, R. P. M., \& Lee, J. S. Y. (2008). The effects of social capital and organisational innovativeness in different institutional contexts. Journal of International Business Studies, 39(4), 589-612. https://doi.org/10.1057/palgrave.jibs.8400373. 
Mason, D., \& Pauleen, D. J. (2003). Perceptions of knowledge management: A qualitative $\begin{array}{llll}\text { analysis. Journal of Knowledge } \quad \text { Management, } & 7(4), \quad 38 .\end{array}$ https://doi.org/10.1108/13673270310492930.

Nonaka, I., \& Takeuchi, H. (1995). The knowledge creating company: How Japanese companies create the dynamics of innovation. New York, NY: Oxford University Press.

Oparaocha, G. (2016). Towards building internal social network architecture that drives innovation: A social exchange theory perspective. Journal of Knowledge Management, 20(3), 534-556. https://doi.org/10.1108/JKM-06-2015-0212.

Quintane, E., Casselman, R. M., Reiche, S. B., \& Nylund, P. A. (2011). Innovation as a knowledge-based outcome. Journal of Knowledge Management, 15(6), 928-947. https://doi.org/10.1108/13673271111179299.

Rasmussen, P., \& Nielsen, P. (2011). Knowledge management in the firm: Concepts and issues. International Journal of Manpower, 32(5/6), 479-493. https://doi.org/10.1108/01437721111158161.

Sankowska, A. (2013). Relationships between organisational trust, knowledge transfer, knowledge creation, and firm's innovativeness. The Learning Organization, 20(1), 85-100. https://doi.org/10.1108/09696471311288546.

Gloet, M., \& Terziovski, M. (2004). Exploring the relationship between knowledge management practices and innovation performance. Journal of Manufacturing Technology Management, 15(5), 402409. https://doi.org/10.1108/17410380410540390.

Van den Hooff, B., \& De Ridder, J. (2004). Knowledge sharing in context: The influence of organisational commitment, communication climate and CMC usage on knowledge sharing. Journal of Knowledge Management, 8(6),117-130. https://doi.org/10.1108/13673270410567675.

The research paper passed the review process. | Received: June 5, 2020; Revised: August 3, 2020; Accepted: August 30, 2020; Pre-published online: December 28, 2020; Published in the regular issue: July 2, 2021. 